\title{
A Guide to Radiation Fixatives
}

\author{
J. J. Tawil \\ F. C. Bold
}

November 1983

Prepared for

the Defense Nuclear Agency

under a Related Services Agreement

with the U.S. Department of Energy

Contract DE-AC06-76RLO 1830

Pacific Northwest Laboratory

Operated for the U.S. Department of Energy

by Battelle Memorial Institute

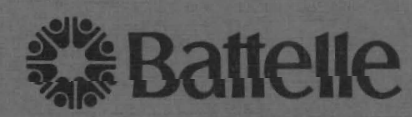




\title{
DISCLAIMER
}

This report was prepared as an account of work sponsored by an agency of the United States Government. Neither the United States Government nor any agency thereof, nor any of their employees, makes any warranty, express or implied, or assumes any legal liability or responsibility for the accuracy, completeness, or usefulness of any information, apparatus, product, or process disclosed, or represents that its use would not infringe privately owned rights. Reference herein to any specific commercial product, process, or service by trade name, trademark, manufacturer, or otherwise, does not necessarily constitute or imply its endorsement, recommendation, or favoring by the United States Government or any agency thereof. The views and opinions of authors expressed herein do not necessarily state or reflect those of the United States Government or any agency thereof.

\author{
PACIFIC NORTHWEST LABORATORY \\ operated by \\ BATTELLE \\ for the \\ UNITED STATES DEPARTMENT OF ENERGY \\ under Contract DE-AC06-76RLO 1830
}

Printed in the United States of America

Available from

National Technical Information Service

United States Department of Commerce

5285 Port Royal Road

Springfield, Virginia 22161

NTIS Price Codes

Microfiche A01

Printed Copy

Pages

Price

001-025

026-050

051-075

076-100

$101-125$

$126-150$

151-175

$176-200$

201-225

226-250

251-275

276-300

Codes 


\author{
J. J. Tawi1 \\ F. C. Bold
}

November 1983

\begin{abstract}
Prepared for the Defense Nuclear Agency under a Related Services Agreement with the U.S. Department of Energy Contract DE-AC06-76RLO 1830
\end{abstract}

\footnotetext{
Pacifc Northwest Laboratory Richland, Washington 99352
} 


\section{SUMMARY}

This report identifies and then characterizes a variety of substances available in the market place for potential effectiveness as a fixative on radiologically contaminated surfaces. The substances include both generic chemicals and proprietary products. In selecting a fixative for a particular application, several attributes of the fixative may be relevant to the choice. These attributes include: toxicity, durability, and cleanliness and removability. In addition to the attributes of the fixative, one should also take into account certain characteristics of the site to be treated. These characteristics relate to climate, nature of the surface, use to which the treated surface will be put, subsequent cleanup operations, and type of neighboring surfaces. Finally, costs and potential environmental effects may influence the decision. A variety of fixatives are evaluated with respect to these various attributes and sumarized in a reference table. 


\section{CONTENTS}

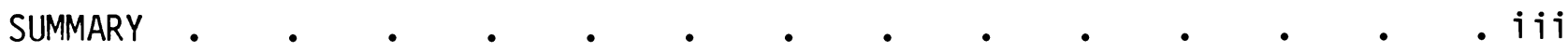

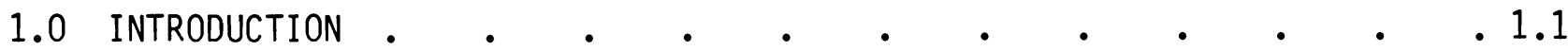

2.0 MAJOR FACTORS AFFECTING CHOICE OF FIXATIVE $\quad$ • $\quad . \quad$ •

2.1 CHARACTERISTICS OF THE MATERIAL $\quad$ • $\quad$ • $\quad$ • $\quad$ • $\quad$ • 2.1

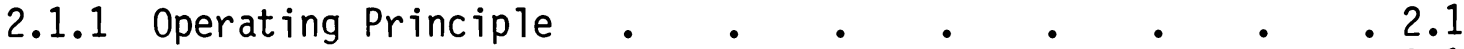

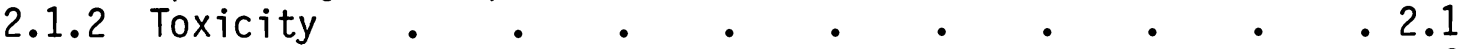

2.1.3 Cleanliness and Removability . . . . . . 2.2

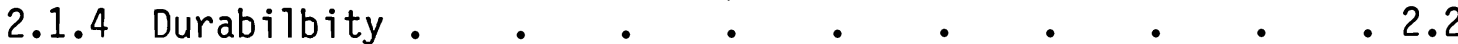

2.2 CHARACTERISTICS OF THE SITE TO BE TREATED $\quad$ • $\quad$ • $\quad$ • 2.2

2.2.1 Climate

2.2.2 Nature of the Surface: $\bullet \quad \cdot \quad \cdot \quad \cdot \quad \cdot 2.2$

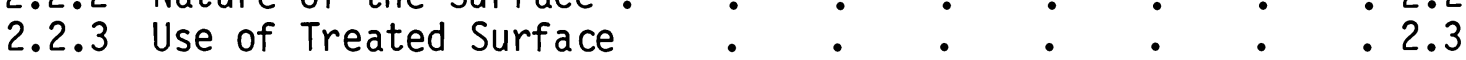

2.2.4 Subsequent Operations . . . . . . . . . . 2.3

2.2.5 Neighboring Surfaces . $\quad . \quad \cdot \quad . \quad . \quad \cdot 2.3$

2.2.6 Environmental Aspects . $\quad . \quad . \quad . \quad . \quad . \quad . \quad .2 .3$

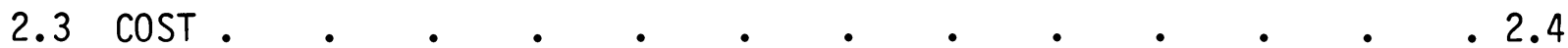

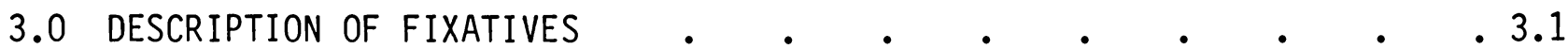

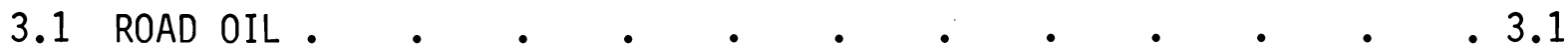

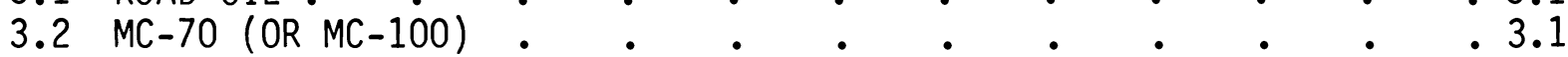

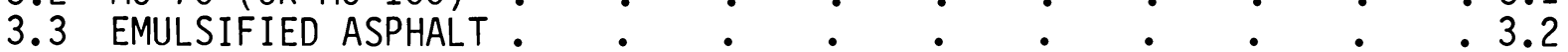

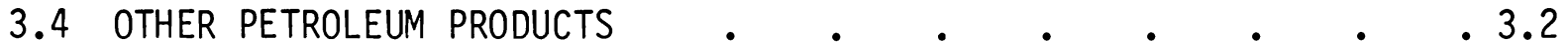

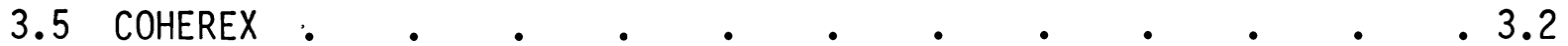

3.6 COMPOUND SP

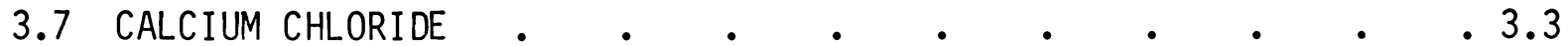

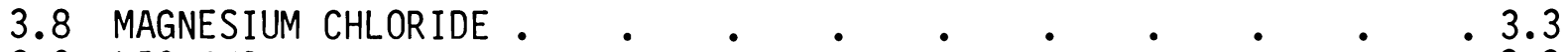

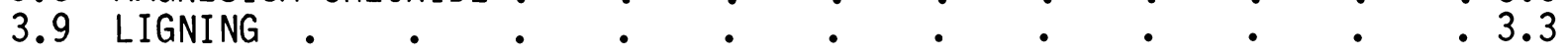

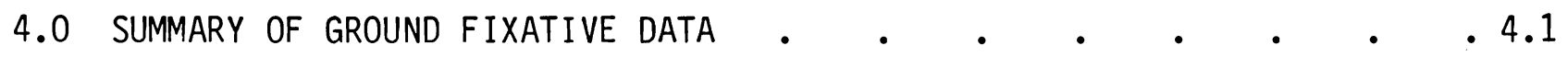

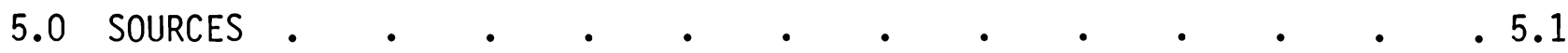




\subsection{INTRODUCTION}

The term "fixative" refers to any material used to bind radioactive particles to a surface. Fixing radioactive contamination to a surface will prevent resuspension of the particles in the air by wind or by other physical disturbance. This is important for two reasons. First, it greatly reduces the health hazard from some radionuclides such as plutonium for which the principle danger is via ingestion or inhalation pathways. Second, this will curtail the spreading of the contaminant to uncontaminated areas or areas which have received a decontamination treatment.

Besides these benefits of preventing resuspension, fixatives can also increase the decontamination efficiency of operations which involve removal of contaminated surfaces. By binding the contaminant to the removed surface, the fixative will assure that a greater proportion of the contaminant is removed with the surface.

There are a variety of substances that could be used as fixatives, including a number of petroleum-based products such as road oil, emulsified asphalt, diesel 011 , and MC-70. Another group of materials which might be useful in this role includes those which are sold for the purpose of dust control and are sometimes called "dust paliatives," "dedustants," or "dust retardants." These include generic products such as calcium chloride, magnesium chloride, and calcium lignosulfonate, and proprietary products such as Coherex and Compound SP. In addition, there are other materials that could be used as fixatives even though that is not their primary function. For example, an application of strippable coating would be effective, though costly. Also, decontaminating foam could be considered a very short-lived fixative. In some cases, even plastic sheeting, paint, or water could be used to prevent resuspension of radioactive particles.

The choice of which fixative to use involves more than just choosing the desired physical characteristics of the fixative material. Selection of the fixative entails several considerations, including: 
- the physical characteristics of the fixative

- the physical characteristics of the surface to be treated

- the application technique

- the costs of the material and application

- the effect of the fixative on ultimate cleanup procedures

This guide is intended to serve as an aid to choosing and applying fixatives. 


\subsection{MAJOR FACTORS AFFECTING CHOICE OF FIXATIVE}

This section describes the most important factors bearing on the choice of fixative for any particular application. These considerations fall into three main categories:
(1) characteristics of the fixatives
(2) characteristics of the particular use
(3) cost

\subsection{CHARACTERISTICS OF THE MATERIAL}

\subsubsection{Operating Principle}

There are two principal ways in which fixatives prevent resuspension. Some form membrane layers over the surface. These include such fixatives as a thin coating of asphalt and Compound-SP. Other fixatives bind with the particles by absorbing into them. Fixatives of this sort include road oil, Coherex, and Polybinder.

Fixatives that bind with the particles rather than coating the surface may operate in different ways. For example, road oil and diesel oil are very slowcuring oils. Calcium chloride, on the other hand, is a hydrophilic chemical. It draws and holds moisture to maintain dampness. Polybinder is sticky when applied but dries afterward, holding particles together.

In some cases, a fixative may operate both as a membrane and a binder. For example, a fixative applied to the ground could absorb into the surface and then cure, forming a membrane incorporating the surface particles.

\subsubsection{Toxicity}

Some fixatives may be toxic to plant or animal life in the area. Further, if the fixative is water soluble, rain may move the fixative into undesired areas. 


\subsubsection{Cleanliness and Removability}

Some fixatives, such as road oil, are particularly messy. While a fixative may be effective and economical, it may cause extensive damage to a surface or require very costly cleanup.

\subsubsection{Durability}

Many fixatives have a limited functional life. For example, Compound-SP 301 has an effective life of one year, road oil has an essentially unlimited lifespan, and calcium chloride in arid areas may require watering or repeated application every few days or weeks. Durability would also be affected by the use and weather to which the fixative is subjected.

\subsection{CHARACTERISTICS OF THE SITE TO BE TREATED}

\subsubsection{Climate}

Climate bears on the choice of fixative in several ways. Hydrophilic fixatives must be able to draw moisture from the air or from liquid water on the surface. In arid areas such fixatives could dry out, losing their fixative ability. Some who use the hydrophilic chemical calcium chloride on dirt roads revitalize its dust-preventing property by periodic watering.

Another climatological consideration is whether it rains so much that a fixative would be eroded away. This could pose an additional hazard if the fixative itself is toxic. Also, climate can affect the ease or difficulty of application. Some petroleum-based products float on water. This means that they should not be applied immediately after a heavy rain. Also, MC-70 must be applied hot, using a special spreader truck. Application would be more difficult in very cold weather.

\subsubsection{Nature of the Surface}

Some fixatives would not be effective on some surfaces. In particular, the two hydrophilic chemicals, calcium chloride and magnesium sulfate, would probably not work well on hard surfaces like walls and floors because these surfaces would tend to dry out too easily; in addition, they would likely be ineffective in binding a contaminant to foliage. 


\subsubsection{Use of Treated Surface}

Some treated surfaces may be subjected to loads, traffic, or abrasion of some kind, thereby affecting the choice of fixative. For example, diesel oil or road oil would tend to be picked up on vehicle wheels, causing the contaminant to be spread to other surfaces. Because of a similar problem with respect to foot traffic, a preferred fixative on floors would probably be one that coated and dried like a paint.

\subsubsection{Subsequent Operations}

The choice of a fixative can affect the efficiency and the cost of subsequent operations to a surface. This is particularly true if the surface is eventually to be cleaned after fixing. For example, applying road oil as a fixative to interior walls would be much less costly than applying strippable coating. However, if the walls were subsequently to be cleaned, strippable coating, which is easily removable, would be preferred to a coating of road oil.

\subsubsection{Neighboring Surfaces}

Since it would not always be feasible to strictly confine the application of a fixative to a particular surface without getting some on neighboring surfaces, the neighboring surface could influence the choice of fixative. For example, road oil may be the preferred choice on lawns, but if it severely soils exterior building walls that are to be cleaned, another fixative may be indicated.

\subsubsection{Environmental Aspects}

Since fixatives may have some toxicity with respect to the environment, any environmental hazard posed by a particular fixative would have to be weighed against the fixative's advantages. It should be noted that in some situations toxicity may be an advantage. Such would be the case if a fixative was applied to land that was to be scraped. A fixative that was toxic to vegetation might preclude the need for clearing prior to scraping. 


\section{$2.3 \underline{\operatorname{COST}}$}

There are three major cost components to fixatives:

0 cost of the material

0 cost of transporting the material to the accident site

0 cost of applying the material

The first of these, cost of the material, is presented in detail in Section 3.0 .

The cost of transporting the fixative to the accident site can comprise well over half the total cost of applied fixative. Fixative materials are generally sold on an F.0.B. basis. These charges are subject to standard freight tariffs, and as such they depend on the locations of the plant and the accident site and the type of material shipped.

The cost of application depends on the method of application, the nature of the surface to which it is to be applied, and the required number of repeat applications.

The two basic methods of applying fixative to ground surfaces are by tank truck equipped with a spray bar and pump, and by airplane. Another method is application by hydroseeder. Application to walls, floors, and roofs would generally be by some spray device such as a paint sprayer. These methods and their costs are described in the NUWAX Reference Manual (Tawil and Bold 1983).

The surface type would generally determine the method of application. Further, the condition of the surface would affect the cost of application. For example, the roughness of the terrain and the amount of plant cover would greatly affect the cost of fixative application on vacant land.

Some fixatives have limited durability and would require repeat application or some sort of revitalization. For example, a suggested dustcontrol program for dirt roads, using calcium chloride, is as follows:

1. Apply 38-percent solution at 0.6 gallons per square yard.

2. Repeat application of 38-percent solution at 0.2 gallons per square yard every six months.

3. Apply water whenever dry. 
In some cases, special procedures could be required. One such procedure would be application in remote areas. The spreader trucks would have to be supplied with a shuttle of "nurse trucks." Other special procedures mentioned include scarification of the ground prior to application, wetting of the ground prior to application, and rolling after application. These measures appear to be designed particularly for treatment of dirt roads. 


\subsection{DESCRIPTION OF FIXATIVES}

This section provides brief descriptions of some materials which could be used as fixatives. Most of the products listed here would be suitable for use on unpaved land. A smaller number would be appropriate for other surfaces such as walls and floors. Not listed are very common materials such as paint, water, and water with detergent, which under certain circumstances could be used as fixatives. Also not listed are strippable coating and decontamination foam, which are both discussed in the NUWAX Reference Manual.

\subsection{ROAD OIL}

The term road oil usually refers to a class of petroleum products designated as SCs. Common grades are SC-70, SC-250, SC-800 and SC-3000. Those with higher numbers have greater viscosity. Also, the RCs are somtimes considered to fall in the road-oil grouping. Road oil has been used effectively at the Nevada Test Site as a fixative. It binds well with soil particles, remaining sticky for a long time. Eventually it cures into a hard aggregate crust incorporating surface materials. Road oil is quite messy, and its widespread application would have damaging environmental effects. Application as a fixative would be at a rate of about 0.4 gallons per square yard.

\subsection{MC-70 (OR MC-100)}

The MCs are another group of petroleum products with several grades, of which MC-70, MC-100, MC-250, MC-800, and MC-3000 are common products. The MCs are "cut-back asphalt"; that is, asphalt diluted with a kerosene distillate and therefore more viscous. The lower-numbered MCs, 1ike MC-70 and MC-100, therefore have greater penetrating power. MC-70 is applied with a special spreader truck that heats the material to about $110^{\circ}-135^{\circ} \mathrm{F}$. The normal coverage rate is from 0.1 to 0.5 gallons per square yard, more of the product being required when the soil is porous and absorbant. After curing, MC-70 will form a thin membrane over the soil surface. However, this membrane will break under the weight of foot or vehicle traffic. MC-70 is used by the Reynolds Electrical and Engineering Company, Inc. (REECo) at the Nevada Test Site. 


\subsection{EMULSIFIED ASPHALT}

Emulsified asphalt has some advantages over other petroleum-based products such as the MCs. Emulsified asphalt does not have to be heated, and since it is water based it is generally easier and cleaner to handle. This product material will form a membrane coating. Possible drawbacks to using emulsified asphalt are reduced penetrating power compared with the MCs and a tendency of the treated soil to ball up if vehicles are driven over it.

\subsection{OTHER PETROLEUM PRODUCTS}

Other petroleum products which might be useful as fixatives include diesel oil, bunker oil and dust oil. Dust oil is currently used by the United States Forest Service on unpaved roads in national forests. However, widespread application of these and other petroleum-based products could have serious environmental effects.

\subsection{COHEREX}

Coherex is the name of a proprietary product of the Witco Co. It is a liquid emulsion of petroleum resins, making a "clean" material compared with road 011 , the MCS, emulsified asphalt and other petroleum products. Further advantages are that Coherex is non-toxic and is diluted with water for application, making the material more environmentally acceptable. Coherex is commonly used on dirt roads and on materials, such as stockpiles of coal, to prevent the resuspension of particulates. It is applied with a water spray truck, and the first application to a dirt road would normally last about six months. Subsequent applications would last about a year.

\subsection{COMPOUND SP}

Compound SP is a product made by Johnson March, Inc. It is an organically based long-chain polymer which can be sprayed undiluted usingg an orchard sprayer or a water spreader truck. The result is a clear, crusty latex surface coating. Coated surfaces require a 24-hour rainless period to cure. After that, the coating will withstand heavy rain but will not support foot or vehicle traffic without breaking. This material will bind like paint to walls or floors. There are two Compound SPS. A coating of Compound SP-301 wil1 last about a year, and Compound SP-400 has a durability of three to four years. 


\subsection{CALCIUM CHLORIDE}

Several companies sell calcium chloride for the purpose of dust control on dirt roads. The Dow Chemical Company makes and sells calcium chloride in pellet, flake and liquid forms under the names Pelladow, Dowflake, and Liquidow, respectively. Calcium chloride is hydrophilic. It works by attracting moisture from the air as it attempts to return to or remain in its natural liquid state. It then forms a liquid coating over the material on which it is placed. The moisture increases interparticle cohesion in the same manner as does water applied to dusty soil. The chemical has a tendency to hold the moisture so that dust suppression is maintained. However, in very arid areas the material will dry out, necessitating periodic applications of water.

\subsection{MAGNESIUM CHLORIDE}

Magnesium chloride is another hydrophilic chemical like calcium chloride. It is used by the Reynolds Electrical and Engineering Co. (REECO) at the Nevada Test Site. They report less success with this product than with Polybinder.

\subsection{LIGNIN}

Lignin is the generic name for a number of products whose main ingredient is a by-product of wood pulp processing called wood liquor or calcium lignosulfonate. Lignin is produced and sold by wood-processing companies including Georgia Pacific and ITT-Rainier. Georgia Pacific sells this material under the name Lignosite. Polychem International, Inc. uses Lignosite as the base for their product Polybinder. Both the lignin Lignosite and Polybinder could be used as fixatives. These lignin products are used for dust control on dirt roads. Unlike calcium chloride and magnesium chloride, they are not hydrophilic and can be used in arid areas without the need for watering. REECo reports successful use of this product at the Nevade Test Site.

Lignin is non-toxic and biodegradable, having a durability of about one year. It is diluted with water and applied with a water spray truck. A candidate for use on walls and floors, it can be washed off with water before it dries. Afterwards, it can be cleaned with a solvent and light scrubbing. 


\subsection{SUMMARY OF GROUND FIXATIVE DATA}

Table 4.1 presents basic fixative cost data for fixatives applied to ground surfaces. The data are presented in the form of a worksheet showing the conversion of the material bulk price to the cost per square meter. Important steps in these calculations include the particular dilution and application rates. The dilution and application rates used here are those recommended by the manufacturer. However, the intended use for many of these products is as a dust-control method on dirt roads. Higher concentrations per square meter might be appropriate for radioactive particles, because a greater level of effectiveness may be required. On the other hand, some surfaces to be fixed will not be subjected to vehicular traffic. This may reduce the amount of fixative required per unit area.

Following is a list of the column headings in Table 4.1 and an explanation of each. These should help clarify the meaning of the table entries.

Fixative, source - Some fixatives listed are actually classes of materials. There are several grades of diesel oil, road oil, emulsified asphalt and MCs.

Price as sold - Some products are sold by weight, some by volume. Prices listed are for largest units sold, reflecting any quantity or volume discounts.

Gallons per unit - If the good is sold by the ton, it is necessary to know the number of gallons per ton or, alternatively, the number of pounds per galion.

Dollars per gallon - This is price as sold divided by gallons per unit sold. Note that this is the price of the material before any dilution.

Dilution - All fixatives listed here that are diluted use water as the dilutant. Dilution rates listed are those specified by the manufacturer as normal, but most sources emphasized strongly that dilution and application rates depend on the particular situation. In general, more water seems to increase the fixative's penetrating power, and this usually improves the fixative's performance. 


\begin{tabular}{|c|c|c|c|c|c|c|}
\hline 鶗 & 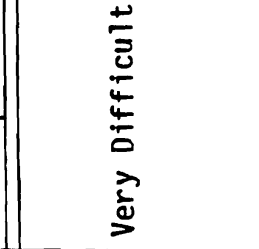 & 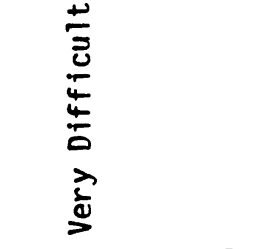 & & 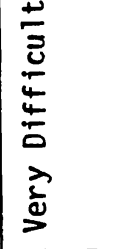 & & \\
\hline : & 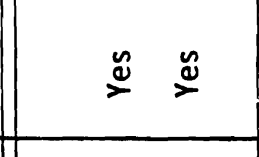 & $\stackrel{2}{2}$ & $\stackrel{1}{2}$ & 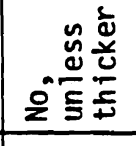 & & \\
\hline $\begin{array}{l}0 \\
0 \\
0\end{array}$ & 党 党 & & & & & \\
\hline 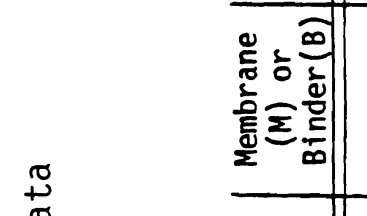 & $\infty \infty$ & 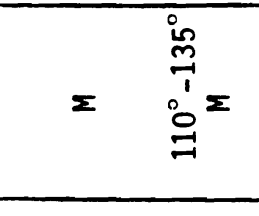 & $=$ & $=$ & $\Sigma$ & $\Sigma$ \\
\hline E & 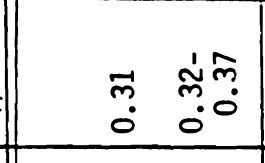 & $\begin{array}{ll}0 & 1 \\
0 \\
0\end{array}$ & $\begin{array}{l}\overrightarrow{0} \\
\dot{0} \\
\end{array}$ & 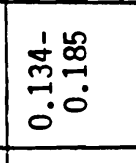 & 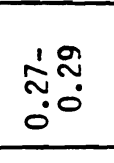 & $\stackrel{\infty}{\circ}$ \\
\hline 嵒 & 葛 & 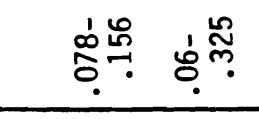 & & 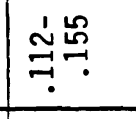 & 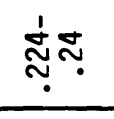 & $\stackrel{?}{?}$ \\
\hline 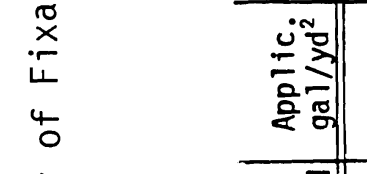 & $\ddot{0} \dot{0}$ & 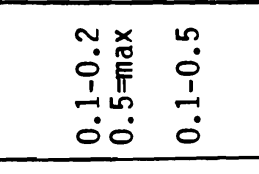 & $\dot{0}$ & 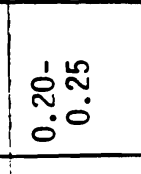 & & $\stackrel{\stackrel{2}{0}}{0}$ \\
\hline 管 & $\begin{array}{l}\Delta \\
0 \\
0 \\
0\end{array}$ & $\begin{array}{ll}\infty & R \\
0 & 0 \\
0 & 0\end{array}$ & & & & \\
\hline 辛 & : & $\vdots$ & & 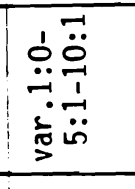 & & \\
\hline 恕 & $\begin{array}{ll}\mathbb{J} & 1 \\
0 & 0 \\
0 & 0 \\
0 & 0 \\
0\end{array}$ & $\begin{array}{ll}\infty & \stackrel{0}{0} \\
0 & 0 \\
\end{array}$ & & \begin{tabular}{|l}
1 \\
0 \\
0 \\
0 \\
0 \\
0 \\
0
\end{tabular} & 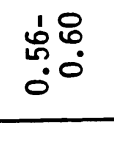 & $\begin{array}{l}: \\
0 \\
\end{array}$ \\
\hline 空 & 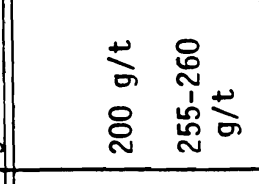 & 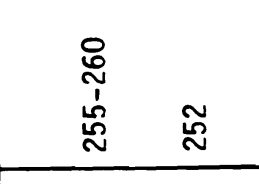 & & $\stackrel{8}{2}$ & $\begin{array}{l}5 \\
0 \\
0 \\
0 \\
\end{array}$ & \\
\hline 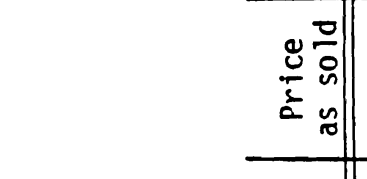 & 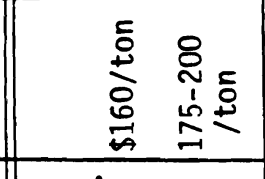 & 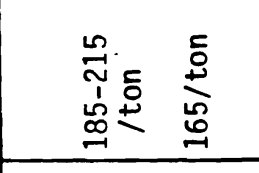 & & 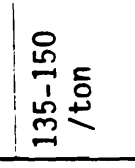 & 告 & \\
\hline 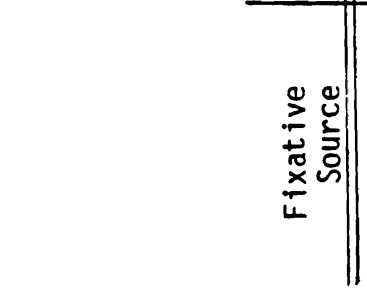 & 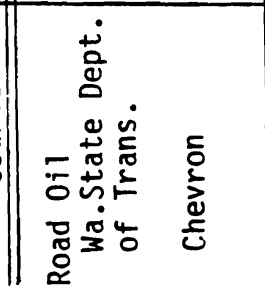 & 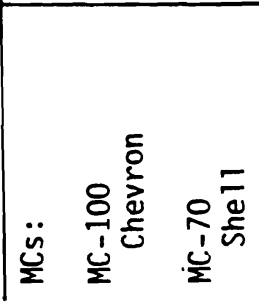 & 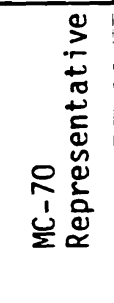 & 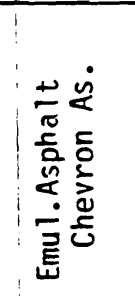 & $\overline{\overline{\mathrm{g}}}$ & 蓆 \\
\hline
\end{tabular}


TABLE 4.1. (cont.)

\begin{tabular}{|c|c|c|c|c|c|c|c|c|c|c|c|c|}
\hline $\begin{array}{r}\text { Fixative } \\
\text { Source } \\
\end{array}$ & $\begin{array}{c}\text { Price } \\
\text { as sold } \\
\end{array}$ & gal/unit & $\$ / g a l$ & Dilution & $\$ /$ dil.gal & $\begin{array}{l}\text { Applic } \\
\text { gal/yd }^{2}\end{array}$ & $\$ / y d^{2}$ & $\$ / \mathrm{m}^{2}$ & $\begin{array}{l}\text { Membrane } \\
(\mathrm{M}) \text { or } \\
\text { Binder(B) }\end{array}$ & $\begin{array}{l}\text { Durability } \\
\text { (years) }\end{array}$ & Load? & Cleanup \\
\hline $\begin{array}{l}\text { Diese } 1 \\
\quad \text { Chevron }\end{array}$ & $90-95 / g$ & 1 & $\begin{array}{r}0.90- \\
0.95\end{array}$ & --- & $\begin{array}{r}0.90- \\
0.95\end{array}$ & $\begin{array}{r}0.20- \\
0.25\end{array}$ & $\begin{array}{l}.18- \\
.24\end{array}$ & & B & & & Difficult \\
\hline $\begin{array}{l}\text { Bunker 0il } \\
\text { Chevron }\end{array}$ & $\begin{array}{r}26-30 \\
/ \mathrm{bb} 1\end{array}$ & $42 \mathrm{~g} / \mathrm{bbl}$ & $\begin{array}{r}0.62- \\
0.71\end{array}$ & -- & $\begin{array}{r}0.62- \\
0.71\end{array}$ & $\begin{array}{r}0.20- \\
0.25\end{array}$ & $\begin{array}{r}.124- \\
.178\end{array}$ & & B & & & Difficult \\
\hline $\begin{array}{c}\text { Emulsifier Dust } \\
0 i 1 \text { - Chev. }\end{array}$ & $150 / t$ & $240 \mathrm{~g} / \mathrm{t}$ & 0.625 & --- & 0.625 & 0.2 & .125 & 0.149 & B & & & \\
\hline $\begin{array}{r}\text { Coherex } \\
\text { Witco }\end{array}$ & $.95 / g$ & 1 & 0.95 & $1: 5 \mathrm{w}$ & 0.158 & 0.75 & .118 & 0.142 & $\begin{array}{c}\text { B } \\
\text { Hydrophilic }\end{array}$ & $\begin{array}{l}.5, \\
1.0 \star\end{array}$ & Yes & $\begin{array}{l}\text { Can be removed } \\
\text { w/ petroleum } \\
\text { solvent, will } \\
\text { stain }\end{array}$ \\
\hline $\begin{array}{l}\text { Compound } \\
\text { SP-301 } \\
\text { Johnson March }\end{array}$ & 2.15. & 1 & 2.15 & --- & 2.15 & $\begin{array}{c}0.09 \mathrm{~g} / \\
100 \mathrm{ft}^{2}\end{array}$ & .1935 & 0.23 & $M$ & 1 & No & $\begin{array}{l}\text { Difficult, binds } \\
\text { like paint, } \\
\text { clear }\end{array}$ \\
\hline $\begin{array}{l}\text { Compound } \\
\text { SP-400 } \\
\text { Johnson March }\end{array}$ & 3.95 & 1 & 3.95 & -- & 3.95 & 0.09 & .3555 & 0.425 & M & 3 & No & \\
\hline $\begin{array}{l}\text { Calc.Chl. } \\
\text { (Peliadow) } \\
\text { Van Waters \& } \\
\text { Rogers }\end{array}$ & $\begin{array}{l}.1317 \\
/ 1 b\end{array}$ & -- & & $\left|\begin{array}{ccc}5 & \text { lbs/gal } \\
38 \% & \text { sol }\end{array}\right|$ & 0.6585 & 0.27 & .1778 & 0.212 & $\stackrel{\text { B }}{\text { Hydrophilic }}$ & $\begin{array}{l}.5(?) \\
w / \text { load }\end{array}$ & Yes & Can be washed off \\
\hline
\end{tabular}




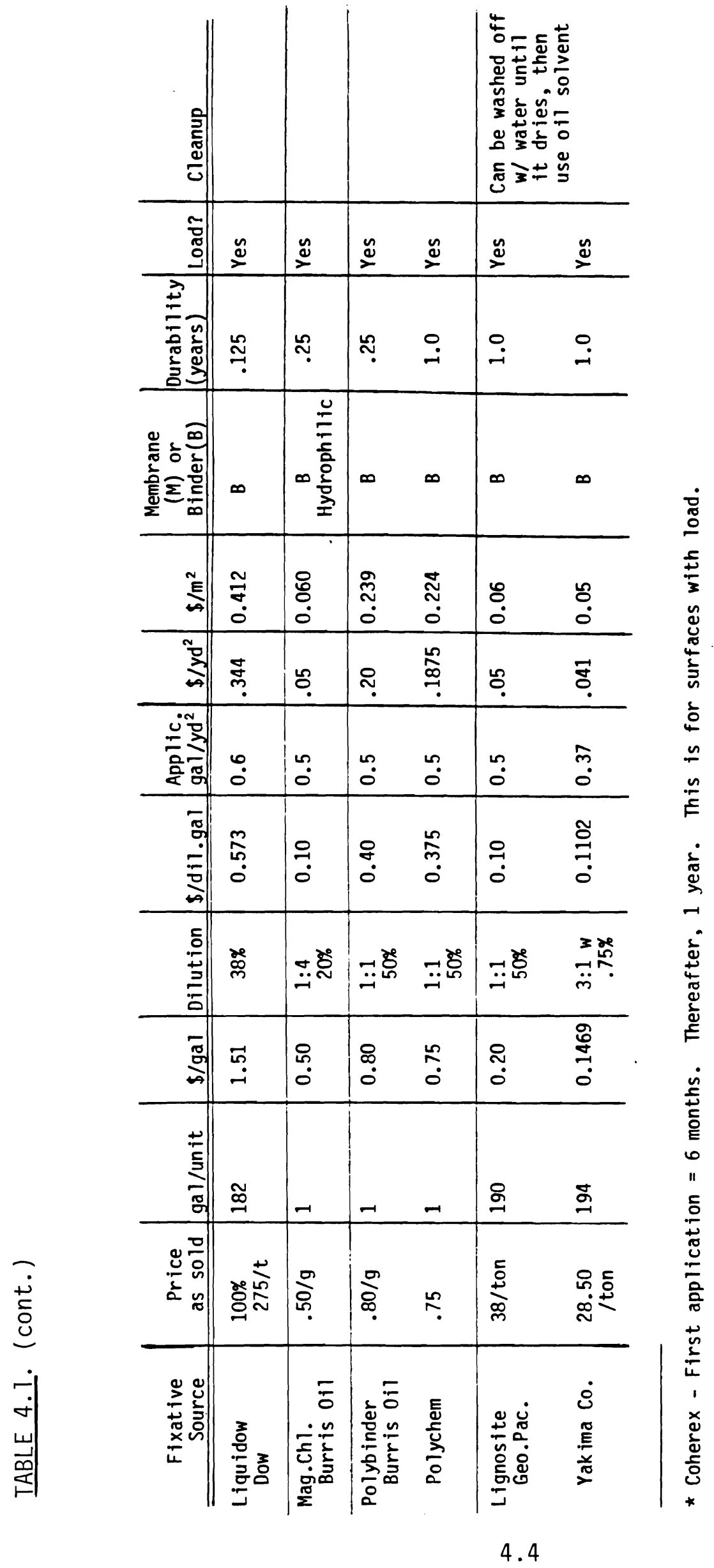


Dollars per diluted gallon - Water is assumed to have zero cost.

Application rate - This is invariably given by the manufacturer as gallons per square yard. Again, this is the normal rate, but rates vary widely depending on soil type and other factors.

Dollars per square yard - This is calculated as dollars per diluted gallon times gallons per square yard.

Dollars per square meter - This is calculated as dollars per square yard times 1.19599 square meters per square yard.

Membrane or binder - This column indicates whether the fixative functions primarily by forming a membrane over the surface or as a binder.

Durability - The average expected lifespan in years is given. These durabilities generally refer to treated surfaces subjected to vehicle traffic unless the next column indicates that the fixative is not suitable for loads.

Load - This column shows whether the fixative can sustain foot- and vehicle-traffic loads.

Cleanup - A rough indication of the prospects for removing the fixative is given here. 


\subsection{SOURCES}

The following list gives the names of organizations and people who generously supplied information and expertise essential to this report.

Burris 0 il

Las Vegas, Nevada

(702) 385-3263

Ed Bickman

Chevron Asphalt Co.

Seattle, Washington

(206) 628-5207

Don Gunn

Dow Chemical Co., Inc.

Bellevue, Washington

(206) $455-7250$

Beverly Fletcher

Georgia Pacific,

Resins and Adhesives Div.

Bellingham, Washington

(206) 733-4410

Jan Draut

Johnson March, Inc.

Philadelphia, Pennsylvania

(215) $668-2800$

Ed Heller

Polychem International, Inc.

Bakersfield, California

(805) 327-0645

Fred Lizalde

Reynolds Electrical and Engineering

Co., Inc.

Nevada Test Site

FTS 546-0470

Gene Kenda 11

FTS 546-2725

Glenn Clayton

FTS 546-2718

Ray Lee
She11 0 il Co.

Laf ayette, California

(415) 283-4211

Andy Johnston

Turco Products

Carson, California

(213) 775-2111

Marv Weiss

Van Waters \& Rogers, Inc.

Bellevue, Washington

(206) 623-6151

Kirk Lider

Witco Chemical Co., Golden Bear Division

Los Angeles, California

(213) 277-4511

Bob LaRue

Yakima County

Department of Public Works

Yakima, Washington

(509) 575-4115

Lee Linger 


\section{DISTRIBUTION}

No. of

Copies

OFFSITE

60 LCmdr. Carl Fesler FCDNA/Capabilities Division Defense Nuclear Agency Kirtland Air Force Base New Mexico 87115

John M. Taylor

Sandia National Laboratory Organization 6231

A1buquerque, NM 87185

Capt. Robert H. Wank

Office of Military Applications

DP 226

Washington, D.C. 20545

Bernie Wise

Instant Response and Development Branch

U.S. Nuclear Regulatory Commission

Washington, D.C. 20555

Joe Logsdon

Office of Radiation Programs

Guides \& Criteria Branch (ANR-460)

U.S. Environmental Protection Agency

Washington, D.C. 20560

27 DOE Technical Information Center
ONSITE

DOE - Richland Operations

H.E. Ransom

31 Pacific Northwest Laboratory Publishing Coordination (2) Technical Information Files(5) Jack Tawil (24) 